\title{
Class II malocclusion with deep overbite: A sequential approach
}

\author{
Fernando Lima Martinelli', Chalana Sangalli Reale ${ }^{2}$, Ana Maria Bolognese $^{3}$
}

\begin{abstract}
Objective: The aim of this case report was to evaluate the results of deep overbite correction by the segmented arch technique. Methods: The first stage of the treatment was performed with this technique to intrude incisors and canines. A maxillary transpalatal bar and a mandibular lingual arch using 0.051-in archwire were employed associated to a facial bow, anchored primarily with occipital pull and, after molar relationship correction, changed to high pull. Results: Upper incisors presented a great amount of intrusion and some palatal root inclination as programmed in the treatment plan. The skeletal mandibular response was favorable to achieve profile balance. Periapical radiograph showed rounded apex of incisor roots, expected in any orthodontic intrusion movement. Conclusion: The clinical results present the successful approach to deep overbite malocclusion.
\end{abstract}

Keywords: Angle Class II malocclusion. Extraoral traction appliances. Tooth movement.

Objetivo: o objetivo desse relato de caso clínico foi avaliar os resultados da correção da sobremordida exagerada por meio da técnica do arco segmentado. Métodos: na primeira etapa do tratamento, utilizou-se essa técnica para intrusão dos incisivos e caninos. Em seguida, foram confeccionados e instalados uma barra transpalatina superior e um arco lingual inferior, ambos com fio de 0,051" de espessura, sendo associados ao arco facial ancorado, primeiramente, em tração occipital e, após a correção da chave de oclusão, foi modificada para tração parietal. Resultados: os incisivos superiores apresentaram grande quantidade de intrusão com discreta inclinação palatal das raízes, conforme determinado no plano de tratamento. A resposta mandibular foi favorável, possibilitando o alcance de perfil mais harmonioso. Nas radiografias periapicais, observou-se suave arredondamento apical nas raízes dos incisivos, compatível com movimento de intrusão. Conclusão: os resultados clínicos conferem sucesso na abordagem da correção da sobremordida exagerada.

Palavras-chave: Má oclusão de Angle Classe II. Aparelhos de tração extrabucal. Movimentação dentária.

\footnotetext{
${ }^{1}$ MSc and PhD in Orthodontics, UFRJ. Associate Professor of the Specialization Course in Orthodontics, PUC/RS.

${ }^{2}$ Specialist in Orthodontics, PUC/RS.

${ }^{3} \mathrm{MSc}$ and $\mathrm{PhD}$ in Orthodontics, UFRJ. Head Professor of Orthodontics, UFRJ.

» The author reports no commercial, proprietary or financial interest in the products or companies described in this article.

» Patients displayed in this article previously approved the use of their facial and intraoral photographs.
} How to cite this article: Martinelli FL, Reale CS, Bolognese AM. Class II maloc-
clusion with deep overbite: A sequential approach. Dental Press J Orthod. 2012 Nov-
-Dec;17(6):76-82.

Submitted: January 23, 2009 - Revised and accepted: October 31, 2009

Contact address: Fernando Lima Martinelli

Rua Mariante, 239/306 - Porto Alegre/RS - Brazil

CEP: 90430-181 - E-mail: flima.martinelli@terra.com.br 


\section{INTRODUCTION}

The Class II malocclusion with deep overbite should be carefully approached in order to reach successful treatment outcomes.9,12 If extrusion of the posterior teeth occurs, steepening of the mandibular plane and downward anterior tipping of the palatal plane would probably be noted. ${ }^{7}$ Thus, the amount of upper incisors exposure and gingival smile are relevant factors to consider in the treatment planning. Avoiding extrusion of the maxillary molars and leveling dentition by incisors intrusion would allow better control of vertical changes. ${ }^{5}$

With the continuous arch technique, the step up or gable bends are properly used in combination with a high pull "J" hook for the intrusion of the anterior segment. ${ }^{18}$ However, some molar extrusion is produced along with that system. For this reason, Burstone ${ }^{1}$ indicates the segmented arch technique to follow incisor intrusion by preventing extrusion of the posterior teeth. Basically, this system consists of the posterior anchorage unit, anterior segment and intrusive arch spring. The posterior anchorage unit includes a $0.018 \times 0.025$-in archwire stabilizing premolars and molars in the right and left sides that are united by means of a lingual or transpalatal bar. The anterior segment will vary between individual cases in the number of dental units and the need for using rectangular archwire. The intrusive arch spring is manufactured on a $0.018 \times 0.022$-in $\mathrm{TMA}^{\mathrm{TM}}$ archwire and a helix may be usefully designed mesially to the first molars. The labial segment of the archwire is placed inside the slot and tied to the intrusive arch spring, which is located in the gingival area of the brackets. ${ }^{1}$

Although this system is applied in the intrusion of upper and lower incisors, extraoral forces can be favorably placed in the maxillary first molars when vertical control is an issue. Merrifield and Cross ${ }^{12}$ infer that the parietal and occipital extraoral traction are both advantageous to intrude upper incisors, while the cervical headgear provides undesirable effects in the correction of deep overbites.

Regarding the magnitude of intrusive forces, $100 \mathrm{gf}$ is recommended to the four upper incisors and $40 \mathrm{gf}$ to all the lower incisors. ${ }^{1}$ Loading within the parameters suggested in literature, root shortening after incisor intrusion is remotely related to age, gender, facial type and the amount of intrusion..$^{10}$ However, there is a high correlation between treatment time and root resorption. ${ }^{10}$

The aim of this study was to discuss the segmented arch principles by evaluating the clinical and radiographic outcomes of the deep overbite correction.

\section{DIAGNOSIS}

The patient was a girl at the age of 13 years whose main complaint was the gingival smile, which is one of the most undesirable esthetical aspects and demands on sufficient growth changes for a favorable prognostic. The vertical balance between the lower third and overall face (Fig 1A), convex profile (Fig 1B) and gingival smile were observed on the clinical examination and extraoral photographs. The dental characteristics were assessed on the clinical exam, intraoral photographs, dental casts and radiographs. Molars and canines showed Class II relationship with an overbite of $80 \%$ and a $4.0 \mathrm{~mm}$ overjet, which denotes the Angle's Class II, division 2 (Fig 1C, 1D). Lower incisors were relatively well positioned on the basal bone without any crowding, while the upper incisors depicted slight retro-inclination. The curve of Spee was moderate in the lower and reverse in the upper arch. Good periodontal health and no inflammatory diseases were detected on the clinical and radiographic evaluations (Fig $1 \mathrm{E}$ and $\mathrm{IF}$ ).

The cephalometric analysis revealed skeletal Class II (ANB $=6^{\circ}$ ) associated with mild mandibular retrusion $\left(\mathrm{SNB}=77^{\circ}\right)$, average mandibular plane angle $\left(\mathrm{GoGn} . \mathrm{Sn}=30^{\circ}\right)$ and favorable vector of facial growth $\left(\mathrm{Y}\right.$ axis $\left.=60^{\circ}\right)$.

\section{TREATMENT OBJECTIVES}

The first step was correcting the deep overbite to allow maximum mandibular response, taking advantage of alveolar growth changes in the molars. The Class II molar relationship was also the primary objective in the treatment plan. Initially, occipital headgear was applied on the first perma- 
nent upper molars. The segmented arch technique was followed in accordance with the principles of Burstone, ${ }^{1}$ but a helix that was $6.0 \mathrm{~mm}$ in diameter was done in each side of the archwire. Hence, the intrusive force was activated with $100 \mathrm{gf}$ in the upper incisors (Fig 2A) and 40 gf in lower incisors. The upper and lower canines were intruded by using forces that were 90 gf e 70 gf, respectively. Then, the intrusion of the incisors and canines altogether was carried out by loading 150 gf and 100 gf, respectively, in the upper and lower arches (Fig 2B). As soon as the molar key of occlusion was achieved, the occipital extraoral force was substituted by the high pull traction attempting to control vertical changes. Finally, the orthodontic treatment was completed through the standard edgewise therapy.
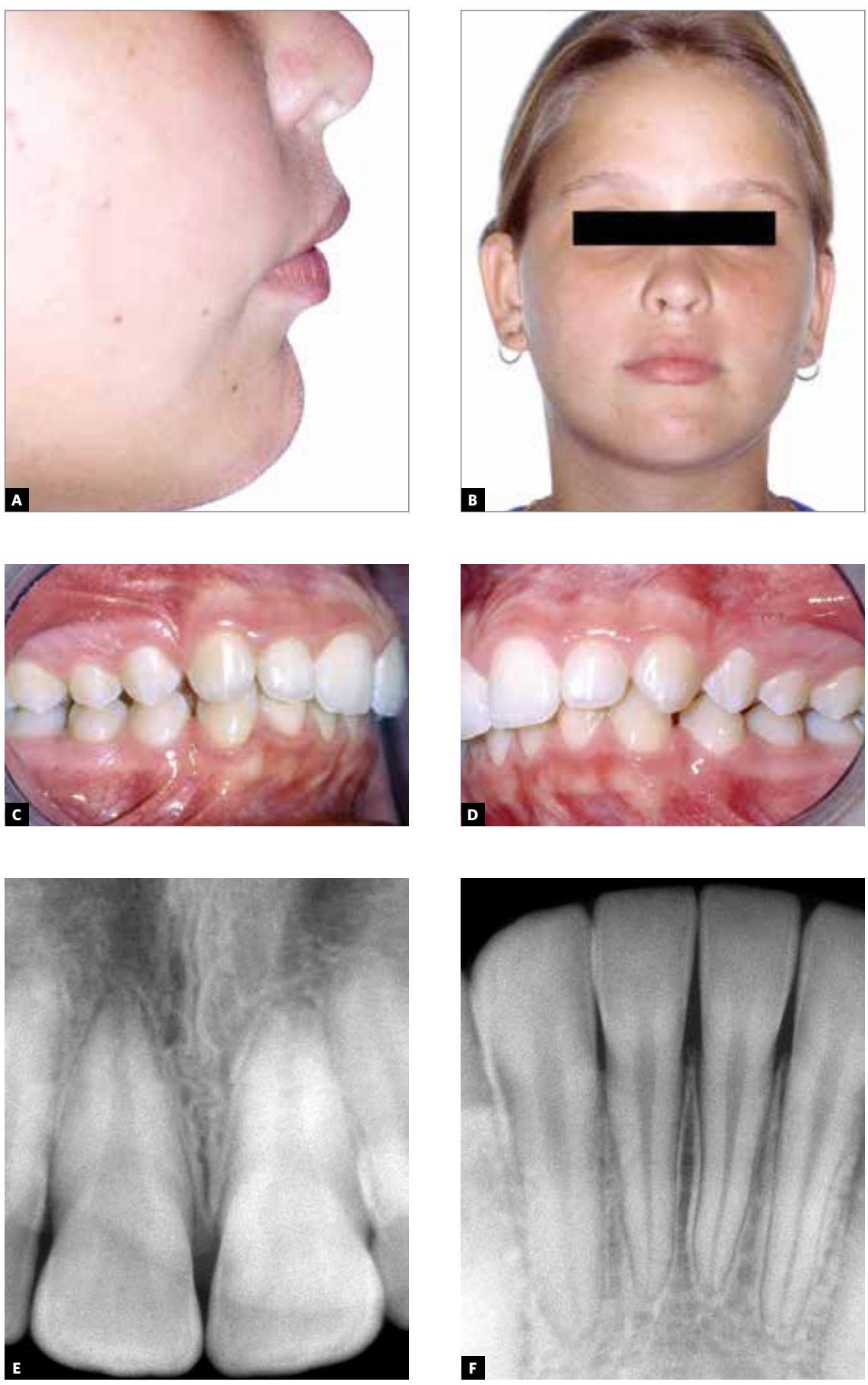

Figure 1 - A, B) Lateral and frontal photographs; C, D) intraoral right and left photographs; E, F) periapical radiographs of upper and lower incisors. 


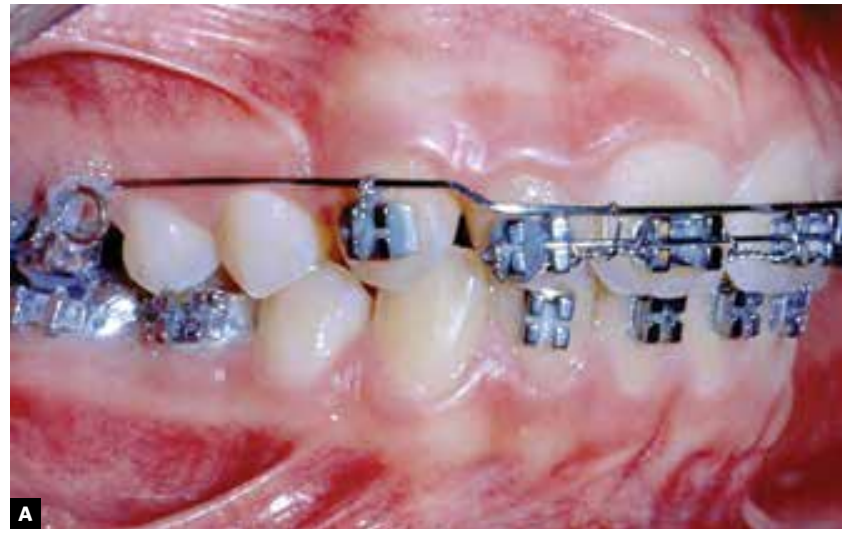

Figure 2 - Segmented arch technique for upper incisor and canine intrusion.

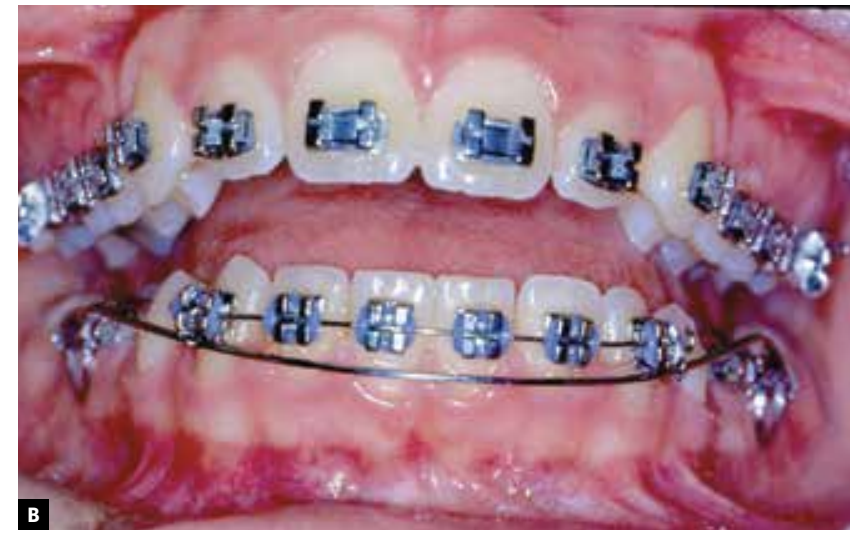

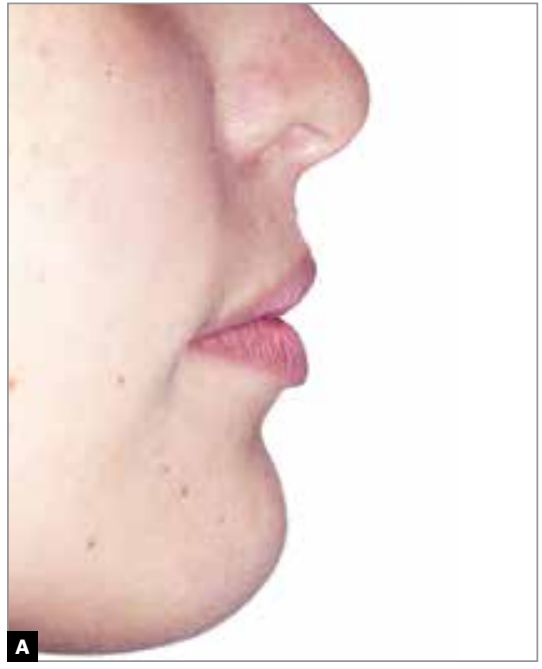

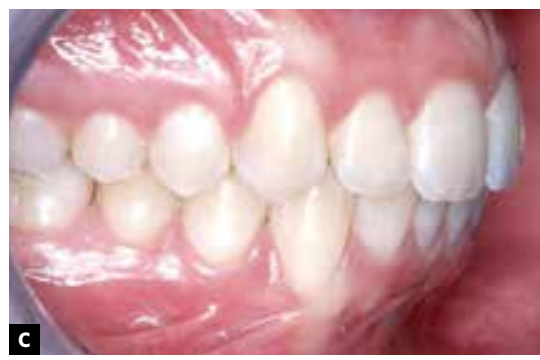

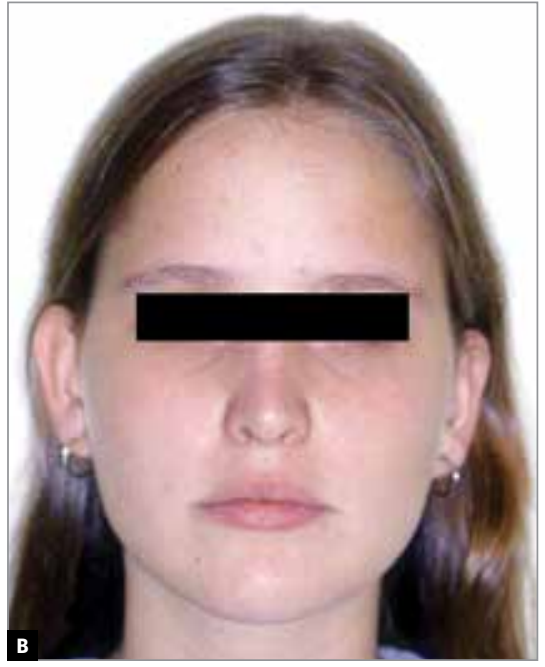

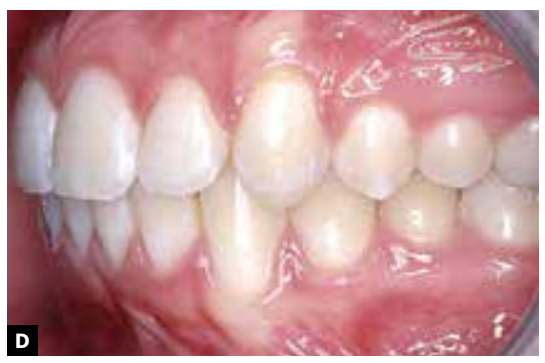

Figure 3 - A, B) Lateral and frontal photographs; C, D) intraoral right and left photographs; E,F) periapical radiographs of upper and lower incisors.

\section{TREATMENT RESULTS}

The original treatment objectives were achieved. The post treatment intraoral photographs show a Class I molar and canine relationship. Overbite was corrected and the gingival smile was also improved (Fig 3A, 3B, 3C, 3D). The final cephalogram and its superimpositions with the pre-treatment tracing show growth of the mandible with just a $2^{\circ}$ opening of the mandibular plane (Table 1). Clinical photographs, radiographs and cephalometric superimpositions depict the final results obtained, when the segmented arch technique was employed to reduce a deep overbite clinical case and finished with standard edgewise technique (Fig 4A, 4B, 4C). 
Table 1 - Cephalometric measurements: T1 - pre-treatment; T2 post-treatment.

\begin{tabular}{|c|c|c|c|}
\hline & Standard & $\mathbf{T}_{1}$ & $\mathbf{T}_{2}$ \\
\hline SNA (degrees) & 82 & 83 & 83 \\
\hline SNB (degrees) & 80 & 77 & 78 \\
\hline ANB (degrees) & 2 & 6 & 5 \\
\hline FMA (degrees) & 25 & 22 & 22 \\
\hline IMPA (degrees) & 87 & 103 & 101 \\
\hline GoGn-SN (degrees) & 32 & 30 & 32 \\
\hline Interincisal (degrees) & 131 & 133 & 130 \\
\hline Upper lip (mm) & 0 & 3 & -1 \\
\hline Lower lip (mm) & 0 & 1 & 0 \\
\hline
\end{tabular}

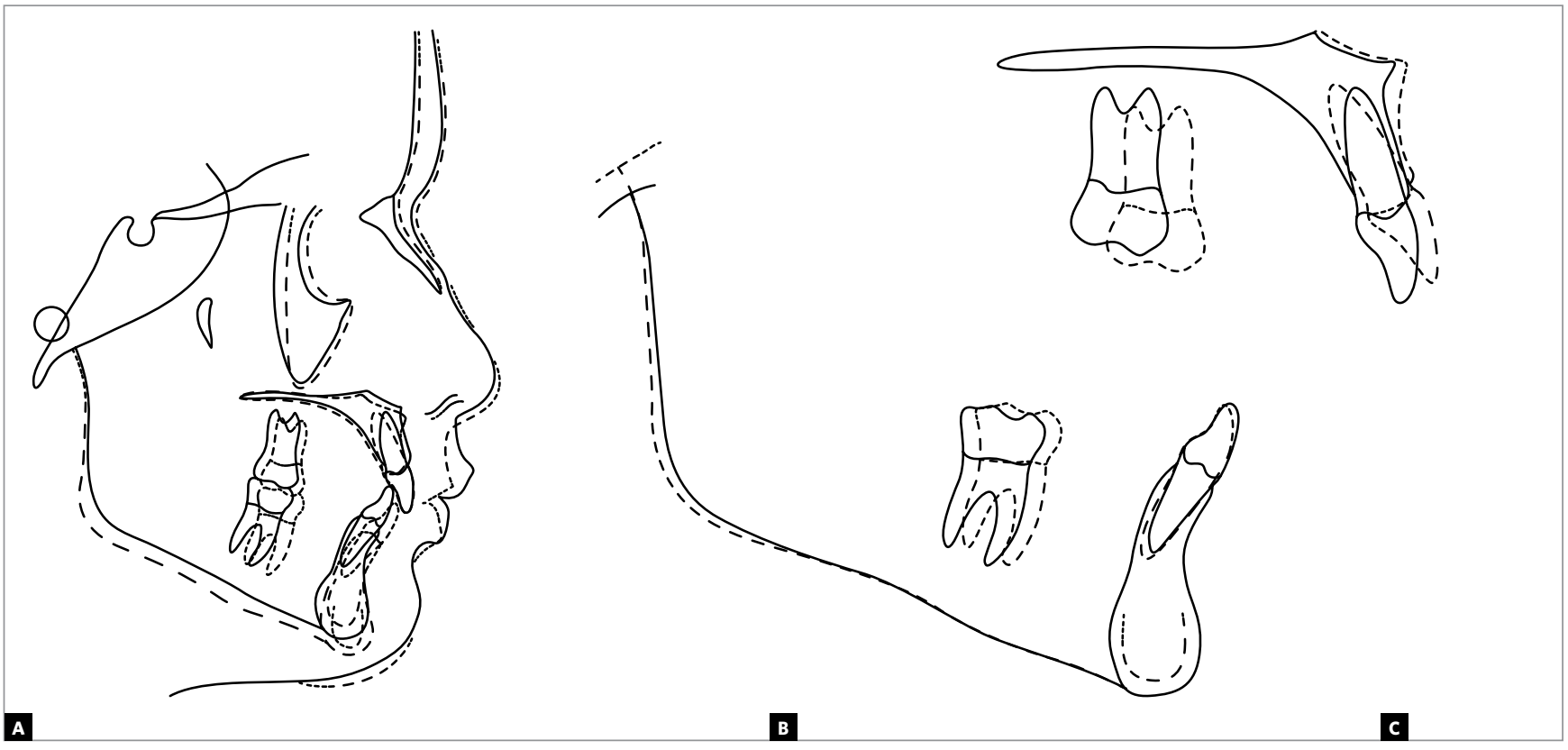

Figure 4 - Cephalometric superimpositions of pre and post treatment. A) registered on S point; B) mandibular movement and C) maxillary movement.

\section{DISCUSSION AND CONCLUSIONS}

A deep overbite can be corrected by genuine intrusion of the anterior teeth, extrusion of the posterior teeth or a combination of intrusion and extrusion. ${ }^{2,3,6}$ The type of tooth movement depends on the treatment objectives and many factors should be considered, including the growth potential of the patient, the vertical skeletal dimension, skeletal convexity, esthetics, stability of final occlusion. ${ }^{19}$

Comparing the continuous arch technique and the bioprogressive method, Dake and Sinclair ${ }^{4}$ demonstrated success in overbite correction with mini- mal increase in mandibular plane angle, greater amount of relapse in the utility arch group, but no incisor intrusion was seen in Tweed's group. The present case report demonstrated incisor intrusion and success in overbite correction using the segmented arch technique associated to favorable mandibular response, as noted mainly in the maxillary superimposition (Fig 4B) and final clinical photographs (Fig 3A, 3B, 3C, 4D).

The natural forward movement of point $B$ and Pog can be inhibited by a deep overbite or also a significant forward-rotating pattern of mandibu- 
lar growth. ${ }^{13,14}$ The apparently enhanced forward movement at point B associated with deep overbite reduction in mesiofacial and brachyfacial subjects is unlikely to be seen at Pog. ${ }^{20}$ This present case report exerted success in overbite correction by means of the segmented arch technique associated to favorable mandibular response and forward movement at point B (Table 1).

Mechanical analysis of continuous arch provides molar extrusion concomitant to incisor intrusion, because the load is not applied on the tooth center of resistance. Segmented arch intrusion method allows to apply the load near the center of resistance, decreasing molar extrusion. This technique dislocates the center of resistance labially, improving vertical control of the buccal segment and correcting incisor exposure. The vertical control was successfully achieved in the treatment reported and the third molar extrusion observed at superimposition was associated to alveolar vertical growth (Fig 4B, 4C). It might be prudent to place fixed lingual retention on the mandibular anterior teeth of deep overbite patients, not allowing mandibular anterior arch width collapse and reduction in the mandibular intercanine width dimension. ${ }^{19}$
According to Kim, Kim, and Lee, ${ }^{8}$ severely extruded and retroclined maxillary incisors can be intruded and proclined with mini-implant and segmented archwire. This can resolve the deep overbite and gingival smile without extruding the maxillary molars and patient's cooperation wearing high-pull headgear is not required. However, another study, showed that the group treated with titanium screws and the group treated with the Tweed-Merrifield technique had excellent vertical control of the maxillary posterior teeth. ${ }^{16}$

Ideal axial inclination of the incisors at the end of treatment could be a factor in overbite stability. ${ }^{13}$ Positioning the mandibular incisor upright over basal bone should improve the stability of the result. ${ }^{3}$ This patient had the mandibular incisors well positioned in basal bone (Fig 4C).

The slight rounded apex observed at final treatment periapical radiography is compatible to any orthodontic intrusion movement (Fig 5A and 5B). According to McFadden, ${ }^{11}$ there is no correlation between the degree of incisor intrusion and root shortening, but it occurs more frequently in upper incisors. This evidence was noted in the reported case treated by segmented arch technique.
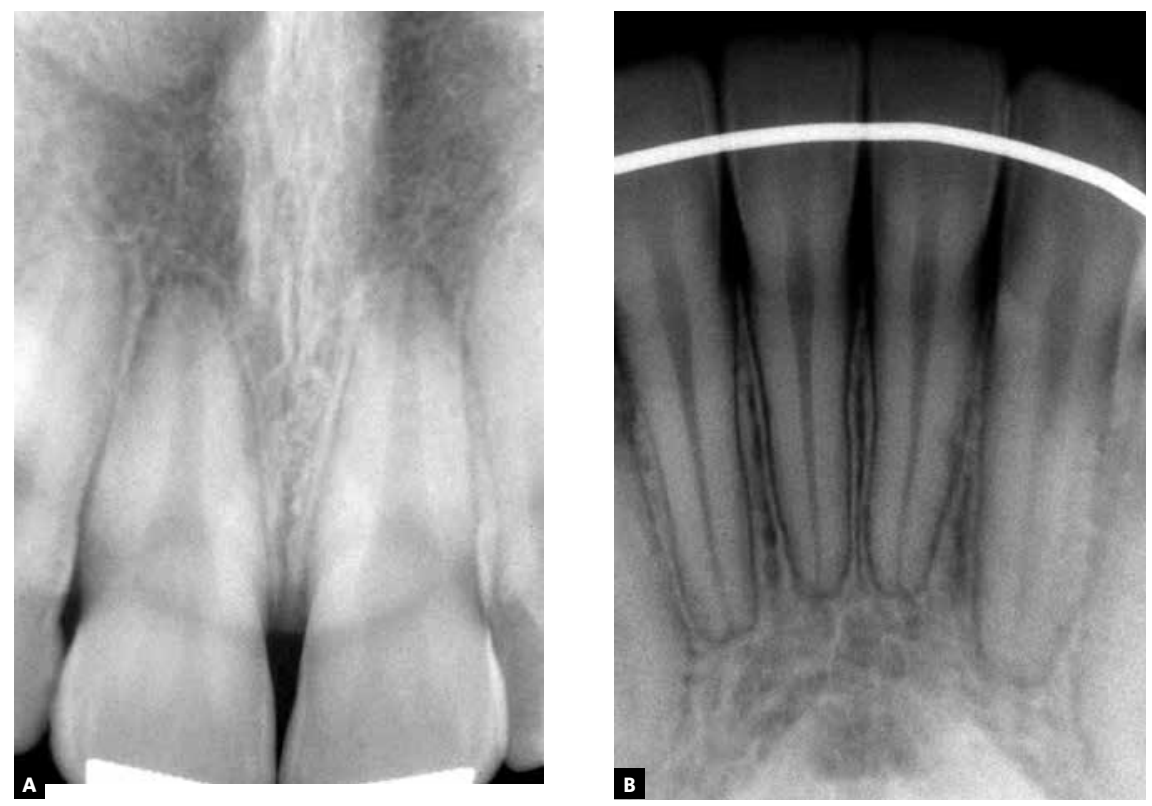

Figure 5 - A, B) Posttreatment periapical radiographs of maxillary and mandibular incisors. 
Studying the relationship between incisor intrusion and root shortening within the load parameters recommended in literature, McFadden ${ }^{11}$ did not find relation between age, gender or facial type and the amount of intrusion or root resorption. However, the author found high correlation between treatment time and root resorption.

The optimal timing for Class II malocclusion treatment remains controversial. Tulloch, Proffit and Philips ${ }^{17}$ mentioned that early treatment should not be thought of as an efficient way to treat most Class II children. In this case report, a one-phase treatment was applied and great results were obtained.

The case reported was treated during pubertal growth and the mandibular response was important to achieve profile balance, but the amount of intrusion is not related to that stage. ${ }^{11,15}$ Otto $^{15}$ demonstrated similar intrusion in both adults and children and found no correlation among incisor intrusion and facial type. Thus, the segmented arch technique is indicated to correct deep bite in adults and children of any facial type.

\section{REFERENCES}

1. Burstone CJ. Deep overbite correction by intrusion. Am J Orthod. 1977;72(1):1-22

2. Brito HHA, Leite HR, Machado AW. Sobremordida exagerada: diagnóstico e estratégias de tratamento. Rev Dental Press Ortod Ortop Facial. 2009;14(3):128-57

3. Chen YJ, Yao CCJ, Chang HF. Nonsurgical correction of skeletal deep overbite and Class II division 2 malocclusion in an adult patient. Am J Orthod Dentofacial Orthop. 2004;126(3):371-8.

4. Dake ML, Sinclair PM. A comparison of the Ricketts and Tweed-type arch leveling techniques. Am J Orthod Dentofacial Orthop. 1989;95(1):72-8.

5. Graber TM, Vanarsdall RL. Orthodontics: current principles and techniques. $2^{\text {th }}$ ed. St Louis: CV Mosby; 2000.

6. Horiuch $Y$, Horiuch M, Soma K. Treatment of severe Class II division 1 deep overbite malocclusion without extractions in an adult. Am J Orthod Dentofacial Orthop. 2008;133(4):S121-9.

7. Hubbard G, Nanda RS, Currier G. A cephalometric evaluation of nonextraction cervical headgear treatment in Class II malocclusion. Angle Orthod. 1994;64(5):359-70

8. Kim TW, Kim H, Lee SJ. Correction of deep overbite and gummy smile by using a mini-implant with a segmented wire in a growing Class II division 2 patient. Am J Orthod Dentofacial Orthop. 2006;126(3):371-8.

9. Lima FR, Lima A, Ruelas ACO. Longitudinal study of anteroposterior and vertical maxillary changes in skeletal Class II patients treated with Kloehn cervical headgear. Am J Orthod Dentofacial Orthop. 2003;73(2):187-93.

10. Martinelli FL, Ruellas AC, Lima EM, Bolognese AE. Natural changes of maxillary first molars in adolescent with esqueletal Class II malocclusion. Am J Orthod Dentofacial Orthop. 2010;137(6):775-81.

11. McFadden WM, Engstron C, Engstroen H, Anholm JM. A study of relationship between incisor intrusion and root shortening. Am J Orthod Dentofacial Orthop. 1989;96(5):390-6.
12. McFadden WM, Engstrom C, Engstrom H, Anholm JM. A study of the relationship between incisor intrusion and root shortening. Am J Orthod Dentofacial Orthop. 1989;96(5):390-6.

13. Merrifield LL, Cross JJ. Directional forces. Am J Orthod. 1970;57(5):435-64

14. Nanda RS, Ghosh J. Longitudinal growth changes in the sagittal relationship of maxilla and mandible. Am J Orthod Dentofacial Orthop. 1995;107(1):79-90.

15. Nanda RS. The rates of growth of several facial components measured from serial cephalometric roentgenograms. Am J Orthod Dentofacial Orthop. 1995;41(9):658-73.

16. Otto RL, Anholm JM, Engel GA. A comparative analysis of intrusion of incisor teeth achieved in adults and children according to facial type. Am J Orthod. 1980;77(4):437-46.

17. Park SH, Yoon DY, Park CS, Jeoung SH. Treatment effects and anchorage potential of sliding mechanics with titanium screws compared with the TweedMerrifield technique. Am J Orthod Dentofacial Orthop. 2008;133(4):593-600.

18. Braun S, Marcotte MR. Rationale of the segmented approach to orthodontic treatment. Am J Orthod Dentofacial Orthop. 1995;108(1):1-8.

19. Tulloch CJF, Proffit WR, Philips C. Outcomes in a 2-phase randomized clinical trial of early Class II treatment. Am J Orthod Dentofacial Orthop. 2004;125(6):657-67

20. Tweed CH. Clinical Orthodontics. $1^{\text {st }}$ ed. St. Louis: CV Mosby; 1966.

21. Walkow TM, Peck S. Dental arch width in Class II division 2 deep-overbite malocclusion. Am J Orthod Dentofacial Orthop. 2002;122(6):608-13.

22. Woods MG. Sagittal mandibular changes with overbite correction in subjects with different mandibular growth directions: Late mixed-dentition treatment effects. Am J Orthod Dentofacial Orthop. 2008;133(3):388-94 